\title{
Salisbury tragedy: the news of the week's narrative of Skripal case
}

\author{
Irina Volkova ${ }^{1, *}$, Leila Algavi $^{2}$, Shuanat Kadyrova $^{2}$ and Natalya Rastorgueva ${ }^{2}$ \\ ${ }^{1}$ RUDN-University, Department of Mass Communication, 6, Miklukho-Maklaya str., 117198, Russian Federation. \\ ${ }^{2}$ RUDN-University, Department of Theory and History of Journalism, 6, Miklukho-Maklaya str., 117198, Russian Federation.
}

\begin{abstract}
This paper is the second part in the series of studies into the media impact on the transformation of the social and cultural structures in which societies operate. The authors (International Research Group KVAR) describe the results of a quantitative and qualitative analysis of transcripts of twenty-seven episodes of the "Vesti Nedeli" television program (Rossiya 1,2018) depicting the mysterious poisoning of Sergei and Yulia Skripal. The aim of this study is to find out in what way the journalists of "Vesti Nedeli" narrate and interpret the events in Salisbury. Based on C. Booker' classification, the authors explore the specific traits of the story plot about the Skripals case. The analysis leads to the conclusion that it is not the Skripals who are at the center of the narration but the United Kingdom and its attitude to Russia. The study identifies the narrative force drivers and the main actors and their subject-object roles: this is one of seven basic plots
\end{abstract}

\section{Introduction}

On March 4, 2018, an elderly man and a young woman were found unconscious in the southeast of Wiltshire in Salisbury (United Kingdom). They were urgently placed in intensive care in a state of coma. Doctors suspected that both were poisoned by "powerful drug fentanyl - a synthetic opiate 50-100 times stronger than heroin".

At first, the event seemed local and insignificant, but it soon became clear that Sergei Skripal, the man who was hospitalized, used to work for GRU, Russian military intelligence agency, and he also worked for the UK's intelligence services.

The police and the press classified the case as a "major incident", suggesting that someone was deliberately trying to kill a Russian spy. Scotland Yard that discovered the Russian trace and the British Foreign Ministry joined the investigation. A few days later, Prime Minister Theresa May made a statement to the House of Commons saying the poisoning was caused by the so called Soviet-era military-grade nerve agent "Novichok". She gave Russia 24 hours to provide "credible response".

So the event turned from a local into an international one. From this point on, the media around the world began to cover both the incident itself and the investigation process, and the phrase "the Skripal case" turned into a meme. Although the characters were the same, the plots of the stories, told in different countries, were strikingly different from one another, forming a meta-plot.

The Skripal case, which became the catalyst for the crisis of Russian-Western relations, was actively discussed by the media around the world. The research group KVAR, considering the story in Salisbury as a kind of continuing media series, focused on the weekly Russian news program "News of the Week" ("Russia-1" TV channel). Studying the news discourse, it is important to show the possibilities of the methodology of Narratology Studies.

Our choice was due to several reasons. First, Dmitry Kiselyov, the host of "News of the Week" program, is known in the West and in Russia as one of the top Kremlin propagandists. Secondly, according to a poll of the Levada Center [1] conducted in March 2018, "News of the Week" (29\%) takes the third place in popularity among TV shows that Russians watch more or less regularly. Thirdly, the program is convenient for narrative analysis, because:

a) unlike the most popular information and political TV show in Russia, "The Night with Vladimir Solovyov" $(34 \%)$, it is in a monologue format, there is only one narrator in each story;

b) transcripts of all the stories are posted on the program website.

It should be noted that D. Kiselyov combines the functions of deputy director of Russian state TV holding company VGTRK and a journalist, and therefore he delivers the information policy of the state-owned TV channel.

The purpose of this article is to identify the hidden, unobvious meaning of D. Kiselyov's interpretation (and, therefore, the Russian federal TV) of the Skripal case.

\section{Methods}

Analyzing the plots of the "News of the Week" program, we constantly kept in mind the following ideas:

\footnotetext{
* Corresponding author: irma-irma@list.ru
} 
1. News is not just a report of facts, but a certain narrative form, originated in oral tradition, popular ballads, tales, myths, etc. Journalists are like folk storytellers: they use conventional narrative tools for the transformation of events and thus they explain a realworld situation in a certain way [2]. It is evident from previous research that news "comes to us as a story" and it consists "enduring, abiding stories". As Lule argues, "We understand our lives and our world through story" [3].

2. Although the narrative analysis is tended to focus on a single story, it is possible to study a cycle of stories combined into a larger metastory, which creates a comprehensive panorama and expands the possibilities and range of discussions. Metastory allows discovering and exploring the holistic world where social action takes place [4].

As Stuart Hall pointed out, before it becomes news, an event should receive the form of a narrative, and gain elements of narrative [5]. Based on the classic work "Narrative analysis: Oral versions of personal experience" [6], the Swiss literary critic Mari-Laura Ryan defined the minimum conditions for the emergence of narratives:

- Events take place in the spatial-temporal extension, in a certain world, which can be both fictional and real;

- This world must undergo not fully predictable changes caused by the unintended or deliberate actions of intelligent agents;

- Changes entail a chain of events that:

a) are linked by a causal relationship;

b) should have a psychological and moral background [7].

In other words, it should be clear what happened, who is responsible for this and why, and what solution to this problem is, and what the moral background of the current situation is.

It follows from the above that the narrative is "a way of organizing spatial and temporal data into a causeeffect chain of events with a beginning, middle and end that embodies a judgment about the nature of the events as well as demonstrates how it is possible to know, and hence to narrate, the event" [8].

So the narrative consists of three dimensions:

1. The factual part, i.e. events, actions, states in their causal-chronological sequence, which Russian scholars call "fabula", and they call it "story" in foreign academic papers;

2. The semiotic interpretation of real or imaginary events with the participation of sentient and sensible subjects arranged in a causal-temporal sequence. The meaning to their actions is determined by the integral configuration and a single value [9]; i.e. sjuzhet or narrative discourse;

3. The media envelope of which "constraints and possibilities are dictated by their material substance and mode of encoding" [7].

Thus, the narrative is the story + the discourse + the media envelope, while the story is the content or chain of events in the storytelling, and the discourse is the form or presentation of the content.
The above-mentioned Jack Lule in his book "Daily News, Eternal Stories: The Mythological Role of Journalism" proves that while covering the current situation in the world, journalists use "a deep but nonetheless limited body of story forms and types" [3]. Lule believes that it happens because people are interested in familiar stories. He argues that the news is "enduring, abiding stories", known among critics as basic [3].

Critics, writers and scholars have made several attempts to define a set of basic plots for nearly a century. The "Morphology of the Folktale" by Propp set this trend [10]. Today, there are several classifications of the basic plots: 4 plots by Jorge Luis Borges [11], 6 plots by Kurt Vonnegut [12], 7 universal plots by Christopher Booker [13], 7 universal myths by Jack Lule [14], 10 news stories by Karl Albrecht [15], 20 basic stories of Ronald Tobias [16] and 36 dramatic situations by Georges Polti [17].

This study focuses on the classification proposed by Christopher Booker. It is based on more understandable story arcs, rather than Vonnegut's emotional arcs. This classification fully correlates with B.Propp's system of functions. The basic myths of Jack Lule correspond more to the typology of archetypal heroes and situations than the plots, as well as the news stories of Albrecht, whose classification seems to be incomplete. However, it should be noted that Albrecht's news situations and Lule's myths fit well into Booker's plot schemes.

To sum up, establishing the basic plot scheme as a part of the storytelling that was chosen by the journalists of "News of the Week" in the course of the narrative formation, it makes possible to detect the ways of covering the Skripal case and the interpretation of the events concerning the poisoning and the police investigation.

\section{Research progress}

The paper examines the materials taken from "News of the Week" as a main source for the analysis, as they explicitly refer to the Skripal case. The total amount of such stories was 27, two of them were co-authored; all of them have been broadcast for eight months (from March 11 to November 30, 2018).

First of all, it was necessary to determine the protagonist of the story, since any plot scheme depends on the main character. Thus, the main characters of the plot schemes "Overcoming the Monster", "Quest", and "Rags to Riches" should be strictly positive. The heroes of "Voyage and Return" and "Comedy" can be negative. It should be noted that spiritual transformation is not a prerequisite for the main character of "Voyage", while spiritual transformation is obligatory for the main character of "Comedy", otherwise the protagonist will be punished, and this genre gets the form of the dark comedy or tragedy.

It is logical to assume that the protagonist is the one who is most often mentioned in the plot. In accordance with the basic elements of the narrative, the characters should be sentient beings ("not only people can act, but 
also anthropomorphized animals, personified natural forces and objects wildlife and mineral kingdom" [18]). Their nature manifests itself through the dynamics of relationships with other characters, which can be revealed by analyzing their statements, cooperating with other persons, their reactions to the opinions of others and applying actions. The actions of these subjects entail a chain of events.

To determine the protagonist and other character, an automatic text analyzer was used. The RSA machine, created in Laboratory \#0-6 "Computational Linguistics and Intelligent Information Analysis" of the Federal Research Center "Computer Science and Management" of the Russian Academy of Sciences. The general principle of this program is:

The text written in natural language $\rightarrow$ Natural
language processing $\rightarrow$ Information extraction
Identification of the verb and Identification of the object)

In other words, at first, relational predicates and their arguments - objects and subjects - are distinguished, and then the characters are determined by the frequency and nature of their interrelationships and the main character is chosen from them. The change of functions of the main characters was accompanied by their semantic roles change, as well.

In determining the main characters, it was taken into account that one of the main methods of transforming an event into a news narrative is personification, when the narrator-journalist focuses on people (persons) and their interests (human interest stories, life stories), not broader socio-political context [19]. As a rule, the personification of international political confrontations takes place in two stages: First, with the help of metonymy, states are animated, and then persons who will become the main characters in the confrontation are identified.

\section{Results}

As a result of computerized text analysis, it was found that in terms of frequency of references and attributed semantic roles, Great Britain is the main character in the "News of the Week" narrative, which is often personified by Prime Minister Theresa May (Teresa May - 95 references, the Prime Minister of the UK - 6). According to "News of the Week" narrative, she was given the semantic role of the Agent - the main initiator of the event, monitoring its progress. Such characters are energetic, active, excitable, have a bright character. In the story of "News of the Week," Teresa May actively interacts with other people, and is essentially the engine of the plot: "drives bullshit" and "encroaches even on the Queen" (March 18, 2018), "declares Russia an ultimatum demanding to admit guilt and explain" (March 25, 2018), "directly deceives the MPs," "she herself invented [...] "Novichok" (March 25, 2018), "persuaded partners to unite against Russia" (March 25, 2018), "charm colleagues" (April 1, 2018) and "tells barefaced lies" (September 9, 2018), etc.
Almost no one opposes her. On the contrary, it is possible to single out a whole group of forces that act on May's side: the United States, the EU countries and the British Commonwealth. Only occasionally does she provoke a response from the Russian authorities: the president of the country, who "declares" (September 16, 2019) and "calmly responds" (April 8, 2018), the foreign minister, who "addresses to Western journalists" (March $18,2018)$ and "reads out the conclusions of the experts" (April 15, 2018), as well as the official representative of the Ministry of Foreign Affairs of Russia, who "warns" (March 18, 2018) "declares" and "doubts" (June 5, 2018).

There is also Victoria Skripal (11 references), the heroine of the people and also Skripal's niece. She really tries to take active steps: "collects documents for a trip to England" (April 01, 2018), "asks questions to the UK government" (August 4, 2018), "addresses her cousin through social networks" (May 6, 2018).

However, on the whole, Russia (or those who personify it) is not more than the object of the protagonist's influence. It doesn't actually take active steps, but only responds to May's actions (Great Britain): Russia expels diplomats in response to the expulsion of its diplomats, appeals to the Organization for the Prohibition of Chemical Weapons (OPCW) after being accused of using weapons of mass destruction in a sovereign state. In fact, Russia endures hardships (collective expulsion of Russian diplomats from $19 \mathrm{EU}$ countries). It is forced to suffer from the short-sighted behaviour of the protagonist (the news program of April 8, 2018 quoted Vladimir Putin as saying: "We expect that common sense will triumph eventually, and international relations will not be suffered such a prejudice, which we have been witnessing lately. This applies not only to the assault on Skripal. This also applies to all other aspects of international relations"). Groundless accusations are heard against Russia ("Therese May has no evidence. None!") (March 18, 2018). In short, Russia is a victim of the UK injustice.

Julia Skripal is the second victim of Great Britain by the number of references in the program (Julia - 19 references, Julia - 2, daughter -22 and once, D. Kiselyov mistakenly called the girl Olga (April 1, 2018). In this story, she plays the role of "the Virgin in trouble" (the image of a young woman in the hands of the villain). This is a positive character. "As far as it is known, Julia has never been associated with the secret services. And her current situation causes a sincere sympathy" (May 27, 2018).

The girl was hidden in an undisclosed location: "Sergei and Julia Skripal are isolated from the outside world" (April 8, 2018), "neither the Consulate of Russia, nor relatives can no longer make contacts with her" (April 15, 2018), "Julia, the daughter of former colonel, is being hidden by the British special services; they explain it by the need to ensure her safety" (May 6, 2018). She herself cannot cope with the situation which she is in: "Scotland Yard makes statements on her behalf, claiming that Julia does not want to see representatives of Russia" (April 22, 2018). In the text, she most often plays the semantic role of the patient, a 
passive participant in a situation that she does not control.

As for Sergei Skripal, even though his surname is found in the headlines of 12 plots, he most often plays the role of a patient-victim in the story itself ("he was poisoned by nerve agent", "was discovered on a bench in a shopping center", "was taken to hospital" etc.).

There are a few more drama actors who are literally suited to the role of Theresa May's victim: the cat Nash Van Drake, two guinea pigs (22 references) and drug addicts, citizens of Great Britain.

The analysis shows that the main character is clearly negative. His actions threaten the rights, freedoms in every way, and what is more, his actions threaten the very existence of others, the "object" that is being vilified and is tend to be monitored. There is "a virgin in trouble" stolen and hidden in an unknown place. There are casual victims in the form of animals and British drug addicts. As shown in Table 1 (Christopher Brooks's basic plot schemes), this arrangement of characters is typical for the tragedy.

Let us consider the phases of the story development.

\section{Anticipation Stage}

The main character appears to us as a negative character, as the titles of the plots eloquently speak of ("British actions resemble Stalin's trials on the Trotskyists" (March 18, 2018) "Skripal Poisoning: "Novichok "was personally invented by Teresa May", "London continues to behave in the style of "Englishwoman shits" (March 25, 2018), "London's Logic: Shoot to Prove Guilt" (April 01, 2018), "The British authorities have carried out the plan of the Nazi criminal" (April 01, 2018), "Faces of London: a liar, a snapper and an I-don't-knowit-all" (April 15, 2018).

What is the dissatisfaction of the protagonist? First, the loss of the country of former greatness. D. Kiselyov believes that the British still have "colonial arrogance" (March 25, 2018). In a program dated March 18, 2018, he claims that by presenting an ultimatum demanding to explain the incident in England before midnight on March 13, Theresa May behaves as if there was the global British Empire and colonies which she had the right to talk with in that way. "In general, there is some savagery in all this. British diplomacy used to be was refined, competent and sophisticated. Now this disheveled straw-headed Boris Johnson is the Minister of Foreign Affairs there", concludes D. Kiselyov.

The second reason for dissatisfaction is problems with Brexit (the UK withdrawal from the European Union). "The government squeezes the most out of this scandal, diverting attention from the disastrous Brexit, which leads this cabinet to a complete collapse. After Salisbury, the ratings of the ruling conservatives have slightly increased", A. Khabarov said in the program on March 18,2018 .

\section{Temptation Stage}

The protagonist chose Russia as an object to focus on. Due to the Scripals poisoning, "the anti-Russian campaign that has been going on in England for more than a year has received an additional impetus," said A. Khabarov in the very first story on the Scripals case (March 11, 2018). They began to discuss the possible expulsion of Russian diplomats in London. "Businessman Browder, who was convicted of fraud in Russia" (March 11, 2018), said to the British parliament that they want to kill him. After that, the protagonist's goal, which was not mentioned at the beginning, is revealed to us: "A radical deterioration in relations with Russia is a swing to new economic sanctions, new military budgets to NATO, tightening the situation in Syria, Nord Stream 2 in Europe, demonizing Russia and abandoning any negotiations with this country, the expansion of cyber war, and even questioning Russia's membership in the UN Security Council. At least, all this was demanded by the members of the British parliament, provoked to a white rage", said D. Kiselyov in the program on March 18, 2018.

\section{Dream Stage}

At first, the situation for the protagonist seemed to be good. On March 8, London filed a complaint with the Organization for the Prohibition of Chemical Weapons (OPCW). On March 14, a meeting of the British Parliament was held, at which Premier Theresa May announced the expulsion of 23 Russian diplomats from London. After that, the British Defence Minister Gavin Williamson stated that "Russia must step aside and shut up" (March 18, 2018). At the EU summit in Brussels, a joint statement was adopted condemning the tragedy in Salisbury. Despite the fact that England was unable to provide strong evidence of Russia's guilt, a "collective expulsion" of Russian diplomats took place, in which "19 countries of the European Union participated" (April 1, 2018).

\section{Frustration Stage}

As interpreted by the authors of the program, the protagonist begins to demonstrate the first signs of disappointment after not all EU countries decide to send Russian diplomats. The broadcast of April 1 shows the words of Slovak Prime Minister P. Pellegrini: "It's useless to put pressure on us, we will not support such a decision for the sake of theatrical gestures," he said. The authors of the program emphasize that the EU countries do not refuse to cooperate and have a dialogue with Russia: "The German authorities fully agreed on the Nord Stream-2 gas pipeline project, and French President E. Macron somehow did not even think about cancelling the visit to Moscow scheduled for May. For the core of the European Union, voluntary participation in this symbolic parade of deportations is a reason to refuse some kind of, maybe, more serious collective nastiness in the future" (April 1, 2018). "London hoped to demonstrate a united front, but at the same time it stuck out the disunity and resentment that the old continental Europe has had to this country for some time" (April 1, 2018).

The main character tries to get his good luck back, but he makes one mistake after another. At first, he burns the dead pets of the Skripals: "Why to burn the material 
evidence? After all, only those who committed the crime act that way. Here, the British are clearly some kind of shortage. They lied, they lied, and at last, they made a slip on guinea pigs" (August 4, 2018). The surviving cat that D. Kiselyov calls "the surviving cat-hero, which remained loyal to its home", was also "caught, killed and burned" (April 8, 2018).

According to the narrative logic, the situation has been changing gradually by 180 degrees: the statements made by representatives of the British ruling circles begin to be refuted not only by Russian politicians and specialists, but also by their foreign colleagues: "Speaking to Sky News, Gary Aitkenhead, the chief executive of the Government's Defence Science and Technology Laboratory, said it was impossible for scientists alone to say precisely where "the Novichok" had been created" (August 4, 2018). The President of the Czech Republic Milos Zeman refuted the British Premier's statement by saying that it was not only Russia which used to produce "the Novichok" (May 6, 2018).

The next mistake is the text of Julia's video message, written in perfect English with a request to leave her alone. "Julia pronounced the text which was obviously written in advance by someone else". The text itself is not a very skillful translation from English (May 27, 2018).

The slip was made when the UK gathered the UN Security Council, on deciding to introduce the suspects, Russian intelligence officers, to the audience. At the same time, it had no evidence, except for "photos of some wild Russians" (September 9, 2018). As a result, "the majority of representatives of the countries did not accept the groundless accusations of Russia" (September 9, 2018).

\section{Nightmare Stage}

From the very first issues, the authors of the program predicted the UK would collapse soon: "Wildness is what explains both the sloppiness in the arguments and the speed of hostile reactions at the level of reflexes. There was England, and it does not exist any longer" (March 18, 2018); "The Skripal case: Britain actually exposes itself" (March 25, 2018); "The relations of Britain with the EU are infused with poison and so is the Skripal case" (April 1, 2018). In the broadcast of September 9, D. Kiselyov said that, "Brexit is the main and most burning problem in London now. Theresa May has a complete failure of hopes for a soft exit from the European Union. EU chief negotiator Michelle Barnier twisted Britain to its will. Theresa May did not even have time to gasp. She was not able to make it".

The appearance of two main suspects in the poisoning, Alexander Petrov and Ruslan Boshirov, helped to put aside the discussion of unsuccessful negotiations on Brexit for some time.

\section{Destruction or Death Wish Stage}

Today, the tragedy is not completed. "News of the Week" has not mentioned the Skripal case since November 18, 2018. However, this does not mean that they forgot about the main character. Beyond the scope of "the Salisbury poisoning" storyline, there is a lot of talk about May; in fact, there is a chronicle of her end. On November 18, D. Kiselyov and A. Khabarov said that the country was in a political crisis, and "four of May's key ministers resigned as a sign of disagreement," and the prime minister, being under constant stress, switched to strong alcoholic beverages, as evidenced by "the bags under her eyes".

On December 16, she "made a tearful speech asking not to fire her". On January 20, 2019, The British Parliament failed the agreement on the UK exit from the European Union. The agreement was proposed by "weird Theresa May who was wearing leopard shoes". This event was called the largest political failure in the last 95 years. Summing up the story, the authors add that "uncertainty is perhaps the softest word for describing the state of chaos in which British policy is in today".

\section{Discussion}

So, there is a question that may arise and which should be discussed: "Is it worth analyzing and drawing conclusions while the story is not over? Isn't the death in the end - the key element, by which the tragedy is determined?"

Although V.I. Tyupa rightly points out that nowadays, the external narrative norms (canon) are relegated to the background, it is obvious that the plot development logic of the Skripal case, as presented by the authors of "News of the Week" cannot be radically changed. This narrative logic leads the main character to death. And since we deal with a real character, it is equally obvious that on March 29, 2019, the day Britain planned to leave the European Union, that very moment will come for Great Britain in general and Theresa May in particular. The moment when "Birnam forest come to Dunsinane". Or will not come.

That narrative line offered by the authors of "News of the Week" can end either with the death of the protagonist (in the case of a big resignation / crisis in the country), or ... nothing, if in reality the Brexit does not happen or happens without particular damage to Theresa May's career and the future of Great Britain as an international player.

In general, the authors of "News of the Week" can refuse to continue the coverage of this story, leaving it unfinished for the audience. The second option is more likely to happen because after November 18, 2018, "News of the Week" completely ignored the newly discovered circumstances of the case, for example, the release of Mark Urban's book about Skripal, or hackers' information about preparing a provocation by the Integrity Initiative group and even the anniversary of poisoning.

However, the unfinished TV story about the Skripals is still a tragedy, just as Dostoevsky's unfinished novel "The Karamazovs Brothers" leaves no doubt concerning its plot. 


\section{The findings}

Taken together, relating to a specific media story, the results of the study indicate the potential of a quantitative and qualitative analysis of news discourse in the tradition of Narratology Studies using the KVAR algorithm.

The story of the Skripals' poisoning, told in "the News of the Week", is a story about a strong UK and a weak Russia. In the narrative of the TV show, Britain appears as a subject of actions, while Russia is an object. The Skripals' poisoning is a cross-cutting theme of the UK-Russia communicative paradigm, and story itself can be labeled as a tragedy. How do these findings relate to the goals of the Kremlin propagandist D. Kiselyov? The question is apparently rhetorical.

All authors - International Research Group KVAR [20] contributed equally to the writing of this paper (the second part in the series of studies into the media impact on the transformation of the social and cultural structures in which societies operate). All authors read and approved the final manuscript. The authors declare that they have no competing interests.

\section{References}

1. Russian non-governmental research organization. Retrieved from: https://www.levada.ru (2018)

2. S. Bird, R. Dardenne, Myth, chronicle, and story: Exploring the narrative qualities of news. In J.W. Carey (Ed.), Media, myths, and narratives (pp. 6787). (Beverly Hills: CA Sage, 1988).

3. J. Lule Daily news, eternal stories: The mythological role of journalism (New York: Guilford, 2001).

4. L. Berdayes, V. Berdayes, The information highway in contemporary magazine narrative. Journal of Communication 48 (2), 109-124 (1998). doi: 10.1111/j.1460-2466.1998.tb02750.x

5. S. Hall, Introduction / A.C.H. Smith, E. Immirzi \&T. Blackwell (Eds.), Paper voices: The popular press and social change (pp. 11-24). (New Jersey: Rowman and Littlefield, 1975).

6. W. Labov, J. Waletzky, Narrative analysis. Essays on the Verbal and Visual Arts, ed. J. Helm (pp. 1244). (Seattle: U Washington Press, 1967).

7. M.-L. Ryan, Defining media from the perspective of narratology. Handelshøjskolen i Århus, Institut for Sprog og Erhvervskommunikation, VÆRK working paper series. Retrieved from http: //pure.au.dk/portal/files/7562/M-L_Ryans_paper.pdf (2013). Accessed 22 May 2019.

8. E. Branigan Narrative Comprehension and the Fiction Film (London: Routledge, 1992).

9. N. Ponomaryov, Storitelling i ritorika v publichnom diskurse [Storytelling and rhetoric in public discourse] // Filologiya v XXI veke: metody, problemy, idei: materialy II Vseros. nauch. konf., 2014. Perm': Perm. gos. nac. issled. un-ta Publ., 151-157. (2014).

10. V.J. Propp, Morphology of the Folktale (Leningrad: Academia, 1928).

11. J.L. Borges, El Oro De Los Tigres (Buenos Aires: Ediciones Neperus, 1972).

12. K. Vonnegut, The Shapes of Stories. In Youtube channel David Comberg. Retrieved from: https://www.youtube.com/watch? $\mathrm{v}=\mathrm{OP} 3 \mathrm{c} 1 \mathrm{~h} 8 \mathrm{v} 2 \mathrm{ZQ}$ (1995)

13. C. Booker The Seven Basic Plots: Why We Tell Stories. The Seven Basic Plots: Why We Tell Stories. (London: Continuum Books, 2004).

14. J. Lule, Daily news, eternal stories: The mythological role of journalism. (New York: Guilford, 2001).

15. K. Albrecht, The (Only) Ten Basic News Stories. How the news producers grab and hold your attention Retrieved from: https://www.psychologytoday.com/intl/blog/brainsn acks/201005/the-only-ten-basic-news-stories (2010).

16. R. Tobias, Master Plots: And How to Build Them. (F+W Media, 1993).

17. G. Polti, The Thirty-Six Dramatic Situations. (Franklin, Ohio: James Knapp Reeve, 1921).

18. P. Mikhailov, B. Mikhailovsky, Plot. Retrieved from: http://feb-web.ru/feb/litenc/encyclop/leb/leb1401.

19. W. Bennett, News content: Four information biases that matter. In W.L. Bennett (Ed.), News: The Politics of Illusion (pp. 28-58). (Chicago and London: The University of Chicago Press, 2003).

20. I. Volkova, L. Algavi, S. Kadyrova, N. Rastorgueva, Let Them Talk as "Encyclopedia of Russian Life": Latent "Accursed Questions» on Russian Television (2017). SHS Web of Conferences 50, 01199 (2018). doi:10.1051/shsconf/20185001199. 